\title{
A comparative study on physical properties of Al-doped zinc oxide thin films deposited from zinc acetate and zinc acetylacetonate by spray pyrolysis
}

\author{
Jako Siim Eensalu, \\ Malle Krunks, \\ Inga Gromyko, \\ Atanas Katerski, \\ Arvo Mere \\ Laboratory of Thin Film Chemical Technologies, \\ Department of Materials \\ and Environmental Technology, \\ Tallinn University of Technology, \\ Ehitajate tee 5, \\ EE-19086 Tallinn, Estonia \\ E-mail: jako.eensalu@gmail.com
}

\begin{abstract}
Herein we present a comparative study on highly transparent, conductive aluminium-doped $\mathrm{ZnO}(\mathrm{AZO})$ thin films deposited by pneumatic spray pyrolysis (PSP) of a zinc acetate based solution and a zinc acetylacetonate based solution on soda lime glass. The structural, optical and electrical properties of the films were studied depending on aluminium content in the precursor solution and substrate temperature during deposition (Ts). The solution used to prepare AZO thin films contained $0.2 \mathrm{M}$ zinc acetate or $0.2 \mathrm{M}$ zinc acetylacetonate and aluminium acetylacetonate between $0-15$ at.\% $[\mathrm{Al}] /[\mathrm{Zn}]$. Substrate temperature was varied from 275 to $450{ }^{\circ} \mathrm{C}$. Transmittance and reflectance spectra were recorded by UV-VIS-NIR spectroscopy. Resistivity, mobility and charge carrier density were determined by four point probe measurements in ambient conditions. According to X-ray diffraction analysis, AZO films are highly c-axis oriented until 2-3 at.\% $[\mathrm{Al}] /[\mathrm{Zn}]$ in the spray solution, depending on zinc precursor. Crystallite size is $25-30 \mathrm{~nm}$ for AZO films deposited at Ts $400{ }^{\circ} \mathrm{C}$. All AZO films exhibited high average optical transmittance of $76-94 \%$ in the visible spectrum $400-800 \mathrm{~nm}$ wavelength range. Eg values ranged from 3.32 in undoped $\mathrm{ZnO}$ to $3.58 \mathrm{eV}$ in in highly doped AZO films deposited from zinc acetylacetonate due to the formation of secondary $\mathrm{AlO}_{\mathrm{x}}$ phases. The lowest resistivities were obtained at Ts $400{ }^{\circ} \mathrm{C}$ for films deposited from zinc acetate, 3-7.5 at.\% [Al]/[Zn] in solution $(0.40 \Omega \mathrm{cm})$ and at $\mathrm{Ts} 400{ }^{\circ} \mathrm{C}, 3-7.5$ at.\% $[\mathrm{Al}] /[\mathrm{Zn}]$ in solution for films deposited from zinc acetylacetonate $(0.47 \Omega \mathrm{cm})$.
\end{abstract}

Keywords: AZO, Al-doped $\mathrm{ZnO}$, pneumatic spray pyrolysis, thin films

\section{INTRODUCTION}

Indium tin oxide (ITO) is one of the most popular transparent conductive oxides (TCO) in industry, but expensive and toxic due to its high concentration of indium [1]. Zinc oxide $(\mathrm{ZnO})$ is a suitable candidate for replacing ITO due to its low price, wide band gap of $3.27 \mathrm{eV}$, good electrical, 
optical properties and stability in a hydrogen plasma atmosphere $[2,3]$. Doped zinc oxide thin films can be applied as window layers in solar cells, electrical contacts in liquid crystals, sensors, optical coatings, transparent electrodes, light emitting diodes among other uses [4-6]. Doped zinc oxide thin film TCOs have been extensively studied as non-toxic and cheaper alternatives to ITO.

Several methods have been used to produce doped and undoped $\mathrm{ZnO}$ thin films, such as magnetron sputtering, pulsed laser deposition (PLD), chemical vapour deposition (CVD), chemical bath deposition (CBD) and spray pyrolysis (SP) [7-9].

Spray pyrolysis deposition (SP) uses a precursor solution which is nebulized by pressure, ultrasonication or an electric field and guided onto a hot plate to deposit metal oxide (MO) thin films. The solvent evaporates during transport, allowing the precursor to thermally decompose into a more stable product. SP is a simple, yet effective method with many advantages. More precisely, easy incorporation of any dopant element by adding it to the feed solution, easily controllable film growth rate and thickness, no need for vacuum or pristine substrates, possibility of layered or composition gradiented films, wide substrate temperature $(T)$ range, low operation costs, no local overheating of the substrate, no constraints on the surface profile, material or dimension of the substrate and seamless integration in a standard complementary metal-oxide-semiconductor (CMOS) process $[10,11]$. The research group at our laboratory has extensive experience in spray depositing indium doped $\mathrm{ZnO}[7,12]$. Al-doping effect on $\mathrm{ZnO}$ films deposited by SP had yet to be studied with this method as part of a larger research topic. For these reasons SP was used in this study to deposit Al-doped $\mathrm{ZnO}$ thin films.

Doping with transition metals using spray deposition has yielded $\mathrm{ZnO}$ films with comparably good optical transmittance and electrical conductivity, although many transition metals are toxic heavy metals [13-18]. The best optical and electrical conductivity results are commonly achieved by doping $\mathrm{ZnO}$ with elements from the boron group (B, $\mathrm{Al}, \mathrm{Ga}, \mathrm{In})$ which act as +3 oxidation state electron donors when substituting $\mathrm{Zn}^{2+}[5,19]$. Indium is the best dopant in terms of optical and electric properties and improved crystallinity of the (002) preferred orientation of doped $\mathrm{ZnO}$ thin films [10]. Aluminium salts are considered inexpensive for doping $\mathrm{ZnO}$ due to the prevalence of aluminium in the environment as well as its low toxicity [3]. Hence, aluminium was chosen as the doping element in this study.

The most common zinc precursors for depositing $\mathrm{ZnO}$ thin films are zinc chloride, zinc acetate and zinc acetylacetonate [5]. Aluminium chloride, aluminium nitrate and aluminium acetylacetonate are the most used Al dopants for AZO spray deposition. These compounds are preferred because they are cheap, highly soluble and decompose at suitable temperatures [10]. Similar results ( $\rho=10^{-1}-10^{-3} \Omega \mathrm{cm}, T=80-97 \%$ ) have been obtained with different combinations of the aforementioned zinc and aluminium sources [5].

It has been found in earlier studies that alongside other parameters, e.g. $T$, dopant concentration, solvent composition [20], deposition time, zinc sources and dopant sources also have an effect on the physical properties of sprayed zinc oxide films [5]. Replacing part of zinc acetate with zinc chloride to essentially co-dope with $\mathrm{Al}$ and $\mathrm{Cl}$ has yielded larger crystallites, higher carrier mobility and consequently lower resistivity in sprayed AZO thin films compared to single zinc source films [21, $22]$. Based on previous studies the critical [Al]/ $[\mathrm{Zn}]$ at.\% ratio for electrically conductive AZO films is considered to be below $6 \%$ with the majority of the results indicating $1-3 \%$ as the optimum $[5,19,20]$.

Previous works by other research groups regarding spray deposited AZO have focused mainly on methanol-water and somewhat less on ethanol-water solvent mixtures. Isopropanol-water solvents have been previously used in our laboratory to deposit In-doped $\mathrm{ZnO}$, but not Al-doped $\mathrm{ZnO}[7,12]$. Therefore, the aim of this study is to provide comparative information on physical parameters of as-deposited $\mathrm{AZO}$ thin films grown by pneumatic SP from an isopropanol-water solution using $\mathrm{Zn}(\mathrm{acac})_{2}$ or $\mathrm{Zn}(\mathrm{ac})_{2}$ as the precursor and $\mathrm{Al}(\mathrm{acac})_{3}$ as the dopant.

\section{METHODOLOGY}

AZO thin films were deposited onto $15 \times 25$ $\times 1 \mathrm{~mm}^{3}$ previously cleaned soda lime glass substrates by PSP in ambient atmosphere. The inner diameter of the two-fluid nozzle was $16 \mu \mathrm{m}$. The average distance between the nozzle and 
the substrate was $25 \mathrm{~cm}$ at an incident angle of $30^{\circ}$. Compressed air with a fixed flow rate of $8 \mathrm{~L} / \mathrm{min}$ was used as carrier gas. The solution flow rate was fixed at $3 \mathrm{ml} / \mathrm{min}$. A molten tin bath was used for substrate heating. The substrate temperature $(T)$ was varied from $275{ }^{\circ} \mathrm{C}$ to $450{ }^{\circ} \mathrm{C}$ with $\pm 5^{\circ} \mathrm{C}$ accuracy.

The solvent used consisted of $50 \mathrm{ml}$ of a mixture of isopropanol (99.5\% v/v, Sigma-Aldrich), deionized water and acetic acid $(99.8 \mathrm{v} / \mathrm{v}$, Sigma-Aldrich) in a ratio of 30:19:1, respectively. Acetic acid was added to prevent the formation of zinc hydroxide in the solution.

Zinc acetate dihydrate $(99 \% \mathrm{w} / \mathrm{w})\left(\mathrm{Zn}\left(\mathrm{CH}_{3}\right.\right.$ $\left.\mathrm{CO}_{2}\right)_{2} \cdot 2 \mathrm{H}_{2} \mathrm{O}$, abbreviated here as $\left.\mathrm{Zn}(\mathrm{ac})_{2}\right)$, and zinc acetylacetonate hydrate $(95 \% \mathrm{w} / \mathrm{w})\left(\mathrm{Zn}\left(\mathrm{CH}_{3}\right.\right.$ $\left.\mathrm{COCHCOCH}_{3}\right)_{2} \cdot \mathrm{H}_{2} \mathrm{O}$, abbreviated here as $\mathrm{Zn}$ $(\mathrm{acac})_{2}$ ), from Sigma-Aldrich were used as precursors for spray depositing AZO thin films due to their low cost, low decomposition temperature and high solubility [10]. The zinc precursor concentration in the solution was $0.2 \mathrm{M}$ in all cases.

Aluminium acetylacetonate $\left(\mathrm{Al}\left(\mathrm{CH}_{3} \mathrm{COCH}-\right.\right.$ $\left.\mathrm{COCH}_{3}\right)_{3}$, abbreviated here as $\left.\mathrm{Al}(\mathrm{acac})_{3}\right)(99 \%$ $\mathrm{w} / \mathrm{w})$, from Sigma-Aldrich was used as an additive to both precursors (1-15 at.\% [Al]/[Zn]). The following $[\mathrm{Al}] /[\mathrm{Zn}]$ ratios were used: $1,2,3,5,7.5$ and 15 at. $\%$.

The film structure and phase composition were characterised by X-ray diffraction analysis (XRD), optical transmittance spectra and van der Pauw and Hall measurements. XRD measurements were executed on a Rigaku Ultima IV diffractometer with $\mathrm{Cu} \mathrm{K}$ al radiation $(\lambda=1.5406 \AA, 40 \mathrm{kV}$ at $40 \mathrm{~mA}$ ) in the range of $25-60^{\circ}$, step width $0.02^{\circ}$, by the $\theta-2 \theta$ method using the silicon strip detector
D/teX Ultra. Crystallite size and lattice constants were calculated using proprietary Rigaku software (PDXL Version 2).

Optical total transmittance and total reflectance spectra were measured in the wavelength range $300-900 \mathrm{~nm}$ on a Jasco V-670 UV-VISNIR spectrophotometer using an integrated sphere. The thickness of the films was calculated from the total reflectance spectra $(400-800 \mathrm{~nm}$ range) using an estimated refractive index of 2.00 in the automated envelope method provided in the Jasco SpectraManager software suite. The average film thickness was $530 \pm 130 \mathrm{~nm}$.

Electrical properties were measured by the four point probe method (MMR Tech Variable Temperature Hall System and H50) at room temperature in the dark using gold plated probe contacts and by applying graphite ink on the samples for a better contact. A $0.64 \mathrm{~T}$ permanent magnet was used for Hall measurements. Individual film thickness was taken into account when measuring electrical properties to reduce error.

\section{RESULTS AND DISCUSSION}

The most important parameters for aluminium-doped $\mathrm{ZnO}$ thin film TCO applications are optical transmittance and resistivity. Therefore, the optimal $[\mathrm{Al}] /[\mathrm{Zn}]$ ratios in the starting solution and $T_{s}$ for AZO films deposited from $\mathrm{Zn}$ (a$\mathrm{cac})_{2}$ and $\mathrm{Zn}(\mathrm{ac})_{2}$ were sought.

\section{Electrical properties}

Resistivity, mobility and charge carrier density were measured for all films, results are presented in Fig. 1. Both undoped and $\mathrm{Al}$-doped $\mathrm{ZnO}$

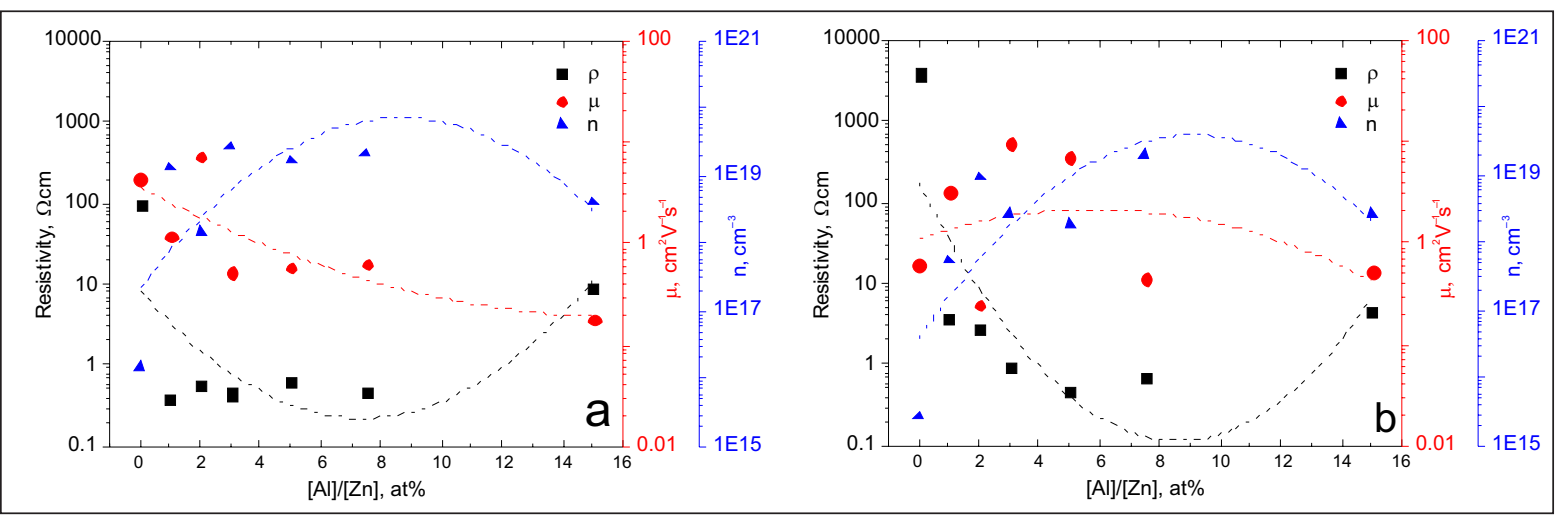

Fig. 1. Electrical parameters of $A Z 0$ films deposited at $T_{s} 400^{\circ} \mathrm{C}$ from (a) $\mathrm{Zn}(\mathrm{ac})_{2}$ or (b) $\mathrm{Zn}(\mathrm{acac})_{2^{\prime}}$ [Al]/[Zn] ratios in solution: 0, 1, 2, 3, 5, 7.5, 15 at.\% 
films exhibit n-type conductivity, as it was determined before and observed in Hall measurements in the current study (Hall constant mark -) [5, 23]. The effect of $\mathrm{Al}$ doping was first investigated based on the best achieved results in literature at $T_{s}-400{ }^{\circ} \mathrm{C}[5]$. Doping with $\mathrm{Al}$ decreases AZO film resistivity by $4-5$ orders of magnitude (Fig. 1b). The difference in resistivity, mobility and charge carrier concentration for films deposited from either zinc precursor is relatively small in the $1-7.5$ at.\% $\mathrm{Al}$ region (Fig. 1). Minimum resistivity at $400{ }^{\circ} \mathrm{C}$ is obtained for $\mathrm{Zn}(\mathrm{acac})_{2}$ based films $(0.5 \Omega \mathrm{cm})$ between $5-7.5$ at.\% [Al]/[Zn] and between $3-7.5$ at.\% $\mathrm{Al}(0.4 \Omega \mathrm{cm})$ in films grown from $\mathrm{Zn}(\mathrm{ac})_{2}$. Gómez et al. obtained minimum resistivity $0.02 \Omega \mathrm{cm}$ with both precursors at 2.5 at. $\%$ $\mathrm{Al}$ in methanol solution and $T_{s} 475^{\circ} \mathrm{C}$, which may be due to many different deposition parameters [9].

At 15 at.\% $[\mathrm{Al}] /[\mathrm{Zn}]$ the film resistivity rises by more than an order of magnitude when 15 at. $\%[\mathrm{Al}] /[\mathrm{Zn}]$ is added to the solution compared to 7.5 at.\% (Fig. 1a, b), possibly due to exceeding the maximum $\mathrm{Al}$ incorporation limit in the $\mathrm{ZnO}$ lattice $[5,9]$. Excess $\mathrm{Al}$ atoms over the critical level may cause intragrain congregation and/ or grain boundary segregation forming $\mathrm{Al}-\mathrm{O}$ clusters $\left(\mathrm{AlO}_{\mathrm{x}}\right)$ from the inevitable thermal decomposition of $\mathrm{Al}(\mathrm{acac})_{3}$ partially into $\mathrm{AlO}_{\mathrm{x}}[6$, 23]. Therefore, 7.5 at.\%. Al was chosen for the temperature series, because the lowest resistivities as well as the highest charge carrier concentrations were obtained for both types of films at this $\mathrm{Al}$ doping level in solution (2.1E19 for $\mathrm{Zn}(\mathrm{ac})_{2}, 2.0 \mathrm{E} 19$ for $\mathrm{Zn}(\mathrm{acac})_{2}$, Fig. 1a, b).

As seen in Fig. 2a, b, minimum resistivity for 7.5 at.\% AZO films deposited from both zinc pre- cursors is attained at $400{ }^{\circ} \mathrm{C}\left(0.7 \Omega \mathrm{cm}\right.$ for $\mathrm{Zn}(\mathrm{acac})_{2}$ and $0.5 \Omega \mathrm{cm}$ for $\left.\mathrm{Zn}(\mathrm{ac})_{2}\right)$. The optimal deposition temperature derived from literature is thereby verified as correct. The same conclusion was reached by many others [5].

\section{Structural properties}

The effect of $T_{s}$ and the ratio of $[\mathrm{Al}] /[\mathrm{Zn}]$ in the starting solution on crystallite sizes and crystallographic orientations was investigated by X-ray diffraction (XRD). The diffraction patterns of AZO thin films deposited from $\mathrm{Zn}(\mathrm{ac})_{2}$ and $\mathrm{Zn}(\mathrm{acac})_{2}$ in different conditions are shown on Figs. 3 and 4. All diffraction patterns are in their original linear scale. According to the XRD patterns (Figs. 3, 4), all films exhibit diffraction peaks at $2 \theta$ of $31.84,34.50,36.34,47.65$ and 56.73 , corresponding to the reflections from the (100), (002), (101), (102) and (110) planes of hexagonal wurtzite type $\mathrm{ZnO}$ (PDF 01-075-0576) [24]. The crystallite sizes were estimated using the (100), (101) and (002) diffraction peak data and the Scherrer equation [25]:

$$
D=\frac{0.94 \lambda}{B \cos \theta}
$$

where $\lambda$ is the wavelength value for the $\mathrm{Cu}-\mathrm{K}_{\mathrm{al}}$ line (1.5406 $\AA$ ), $\beta$ is the FWHM in radians, and $\theta$ is the Bragg diffraction angle.

$1-3$ at.\% $[\mathrm{Al}] /[\mathrm{Zn}]$ films deposited from $\mathrm{Zn}(\mathrm{ac})_{2}$ at $400{ }^{\circ} \mathrm{C}$ are highly c-axis orientated, i.e. the preferred orientation is (002) while crystallites in 5-7.5 at.\% films are (101) oriented (Fig. 3a), which is consistent with previous publications $[19,26]$. Even in the 15 at.\% $\mathrm{Al}$ film no secondary $\mathrm{AlO}_{\mathrm{x}}$ phases were detected.

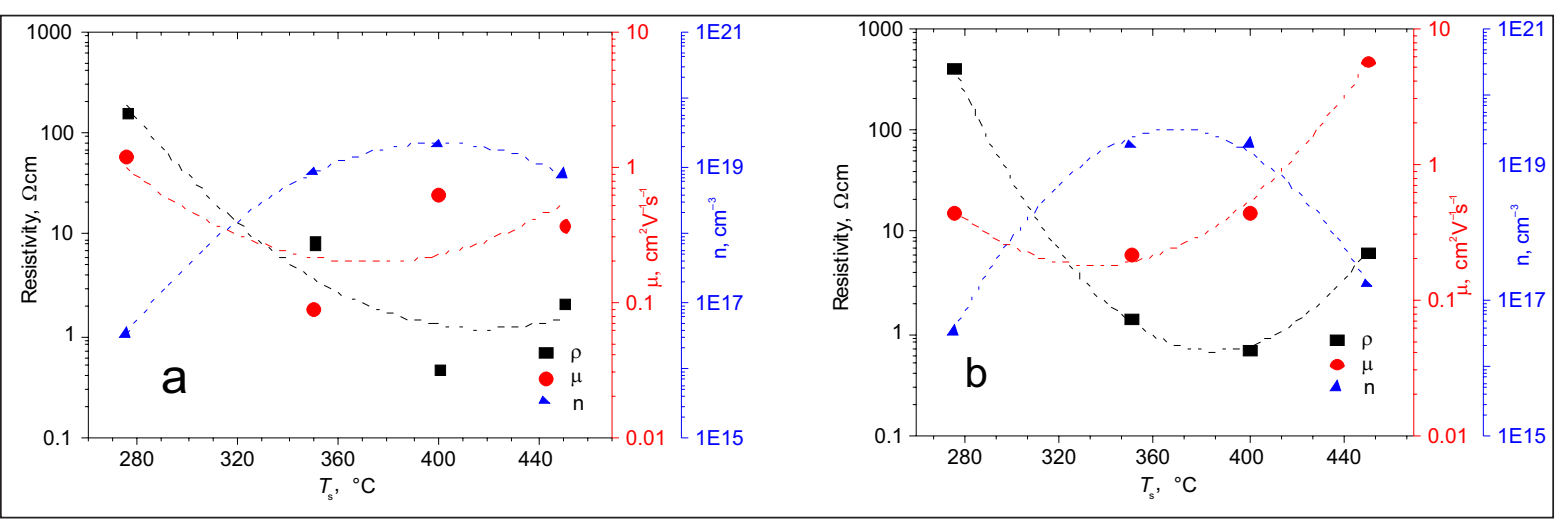

Fig. 2. Electrical parameters of AZO films deposited at various temperatures from (a) $\operatorname{Zn}(\mathrm{ac})_{2}$ or (b) $\operatorname{Zn}(\mathrm{acac})_{2^{\prime}}[\mathrm{Al}] /[\mathrm{Zn}]$ ratio 7.5 at.\% in solution 


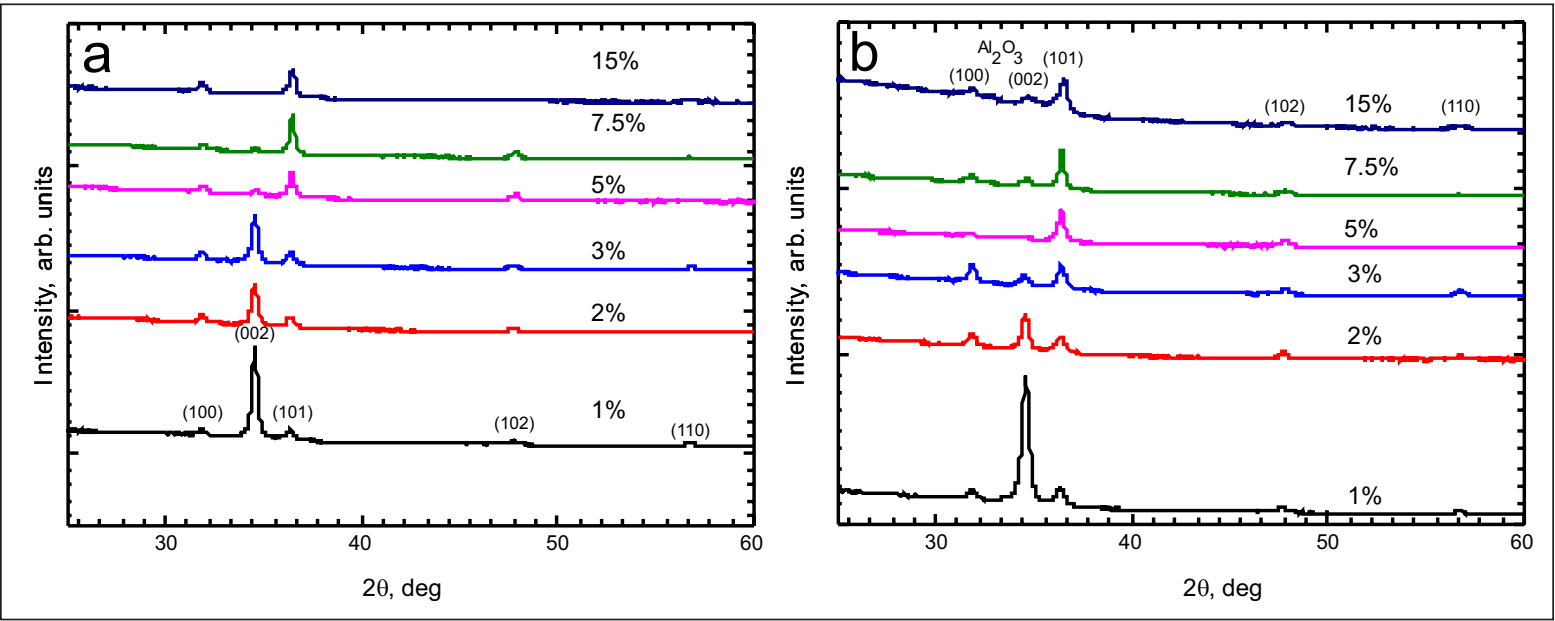

Fig. 3. XRD patterns of $A Z O$ thin films prepared from $50 \mathrm{ml}$ of $0.2 \mathrm{M}$ (a) $\mathrm{Zn}(\mathrm{ac})_{2}$ or (b) $\mathrm{Zn}(\mathrm{acac})_{2}$ doped with $\mathrm{Al}(\mathrm{acac})_{3}$ at $T_{s} 400^{\circ} \mathrm{C}$. $[\mathrm{Al}] /[\mathrm{Zn}]$ ratios in the solution: $1,2,3,5,7.5,15$ at.\%

The gradual degradation for film crystallinity, indicated by smaller peak intensities, is attributed to increased $\mathrm{Al}$ doping levels in the $\mathrm{AZO}$ film [5].

AZO films deposited from $\mathrm{Zn}$ (acac), lose their c-axis orientation between 2 and 3 at.\% [Al]/[Zn] (Fig. 3b). Crystallites are randomly oriented in films grown from $\mathrm{Zn}(\mathrm{acac})_{2}$ beyond 3 at. $\% \mathrm{Al}$ (Fig. 3b). This could mean that the zinc precursor affects the shift in preferred orientation from the (002) plane to the (101) plane. This change in preferred orientation of doped $\mathrm{ZnO}$ was previously reported by numerous other research groups $[5,9,27]$. Also, in the 15 at. $\%$ Al film a sec- ondary peak was detected at 32.91 degrees, indicative of the presence of a separate $\mathrm{Al}_{2} \mathrm{O}_{3}$ phase.

The relative intensities of diffraction peaks for films grown from both precursors are somewhat different, with $\mathrm{Zn}(\mathrm{ac})_{2}$ producing higher crystallinity and stronger (101) preferred orientation than $\mathrm{Zn}(\mathrm{acac})_{2}$ in AZO films deposited by SP at $T_{s} 350-450{ }^{\circ} \mathrm{C}$ (Fig. 4a, b). AZO films deposited at $275{ }^{\circ} \mathrm{C}$ from both precursors are randomly oriented. $\mathrm{Zn}(\mathrm{acac})_{2}$ based film diffractograms exhibit wider and lower diffraction peaks, meaning the average crystallite size must be smaller. This is confirmed in Table 1 with 7.5 at.\% films deposited from $\mathrm{Zn}(\mathrm{acac})_{2}$ containing on average
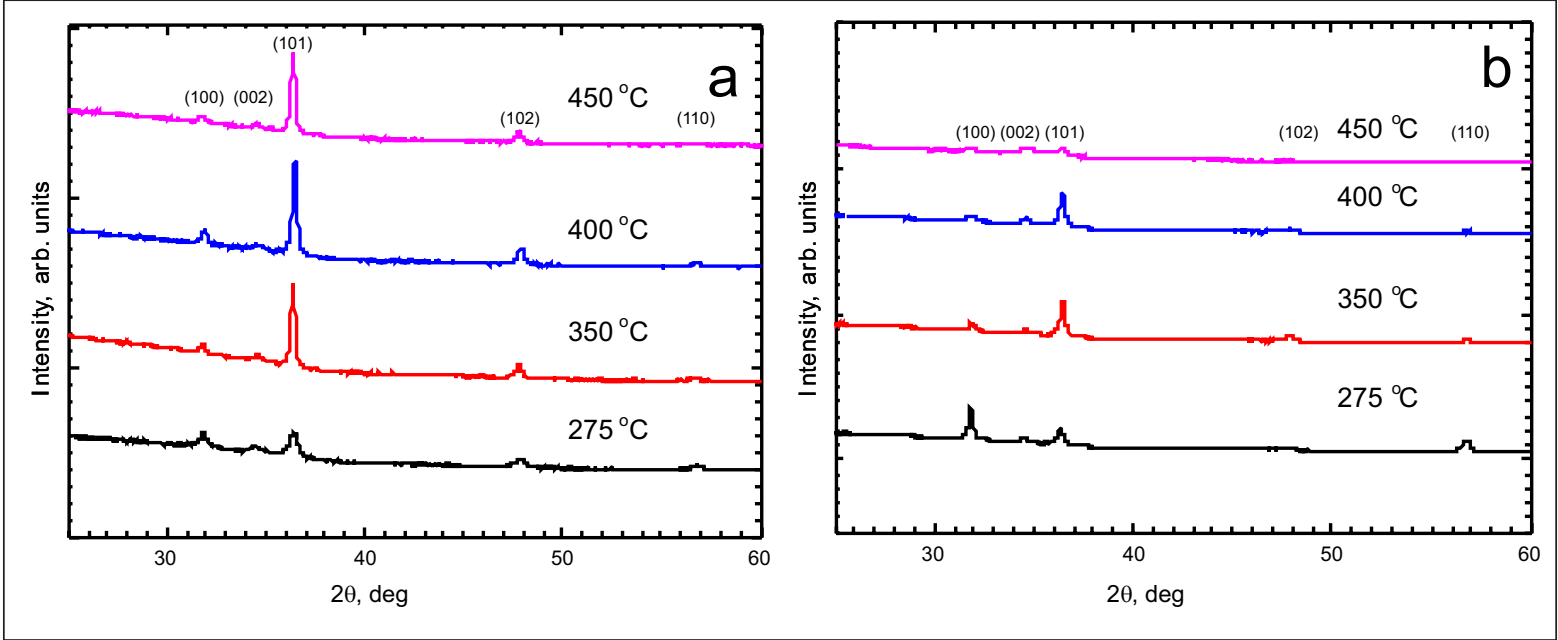

Fig. 4. XRD patterns of AZO thin films prepared from $50 \mathrm{ml}$ of $0.2 \mathrm{M}$ (a) $\mathrm{Zn}(\mathrm{ac})_{2}$ or (b) $\mathrm{Zn}(\mathrm{acac})_{2}$ doped by $\mathrm{Al}(\mathrm{acac})_{3}$ at different $T_{s}$ with [Al]/ [Zn] ratio 7.5 at.\% in solution 
30 vs $40 \mathrm{~nm}$ sized crystallites in films deposited from $\mathrm{Zn}(\mathrm{ac})_{2}$.

The only anomaly is the randomly oriented film grown from $\mathrm{Zn}$ (acac), at $450^{\circ} \mathrm{C}$ in contrast to the strongly (101) oriented film grown from $\mathrm{Zn}(\mathrm{ac})_{2}$ (Fig. 4a, b). The anomalous film shows strong broadening and reduced intensity of the diffraction peaks. The PDXL software determined the diffraction peaks at $2 \theta$ of $31.65,34.57$, $36.37,47.72$ and 56.72 degrees, which probably belong to $\mathrm{ZnO}$ and $\mathrm{Zn}_{6} \mathrm{Al}_{2} \mathrm{O}_{9}$ (PDF No. 00-0510037). This discrepancy needs to be studied further.

The crystallite size in 7.5 at.\% Al AZO films deposited from $\mathrm{Zn}(\mathrm{ac})_{2}$ is about $20 \mathrm{~nm}$ at $T_{s}$ $275^{\circ} \mathrm{C}$, increasing to about $40 \mathrm{~nm}$ between $T_{s}^{s}$ $350-450{ }^{\circ} \mathrm{C}$ (Table 1). This could mean that the films grown below $T_{s} 350{ }^{\circ} \mathrm{C}$ are formed of smaller crystallites containing impurities, which hinder film conductivity (Fig. 2), [5]. Crystallite size for films deposited from $\mathrm{Zn}(\mathrm{acac})_{2}$ is consistently about $30 \mathrm{~nm}$ at $T_{s} 275-400{ }^{\circ} \mathrm{C}$ (Table 1). Undoped $\mathrm{ZnO}$ films deposited from $\mathrm{Zn}(\mathrm{ac})_{2}$ exhibit somewhat larger crystallites $(58 \mathrm{~nm})$ than their counterparts from $\mathrm{Zn}(\mathrm{acac})_{2}(40 \mathrm{~nm})$. Crystallite size in films deposited at $T_{s} 400{ }^{\circ} \mathrm{C}$ from 1-5 at.\% $\mathrm{Al}$ solutions is on average $29 \mathrm{~nm}$ in $\mathrm{Zn}(\mathrm{ac})_{2}$ based films and $22 \mathrm{~nm}$ in $\mathrm{Zn}(\mathrm{acac})_{2}$ based films. Similar crystallite sizes for AZO films grown from $\mathrm{Zn}(\mathrm{acac})_{2}$ and $\mathrm{Al}(\mathrm{acac})_{3}$ have been reported in literature $(33 \mathrm{~nm}$ at 1 at. $\% \mathrm{Al}$ to $20 \mathrm{~nm}$ at 5 at. $\% \mathrm{Al}$ at $T_{s} 500^{\circ} \mathrm{C}$ ) [6].

The only exception is the aforementioned anomalous film deposited at $450{ }^{\circ} \mathrm{C}$ from $\mathrm{Zn}$ (acac), whose crystallites are much smaller than other 7.5 at.\% [Al]/[Zn] films deposited from the same precursor $(9 \mathrm{vs} 30 \mathrm{~nm})$ or at the same temperature from $\mathrm{Zn}(\mathrm{ac})_{2}$ (9 vs $44 \mathrm{~nm}$ ) (Table 1). The film is nearly amorphous and probably consists of a different phase altogether, as mentioned before. Mobility for the anomalous AZO film is an order of magnitude higher than for other films of the same temperature series or the 7.5 at.\% $[\mathrm{Al}] /[\mathrm{Zn}]$ sample deposited from $\mathrm{Zn}(\mathrm{ac})_{2}$ (Fig. 2a, b). Usually, mobility decreases when grain size decreases, so some mobility enhancing phenomena must be affecting the anomalous film [5].

\section{Optical properties}

Figure 5 shows the optical total transmittance spectra of aluminium-doped $\mathrm{ZnO}$ films deposited at different $T_{s}$ from (a) $\mathrm{Zn}(\mathrm{ac})_{2}$ or (b) $\mathrm{Zn}$ (acac) ${ }_{2}$ with constant $[\mathrm{Al}] /[\mathrm{Zn}]$ ratio 7.5 at.\%. All the films are highly transparent, exhibiting 76 to $94 \%$ average transmittance in the wavelength region (400-800 $\mathrm{nm}$ ). The band edge does not shift significantly nor does average transmittance $(\sim 87 \%)$ decrease at any temperature for $\mathrm{Zn}(\mathrm{ac})_{2}$ based AZO films in the films deposited at $T_{s} 350-450{ }^{\circ} \mathrm{C}, 7.5$ at. $\%[\mathrm{Al}] /[\mathrm{Zn}]$ in solution,

Table 1. Crystallite sizes for AZO films deposited at $T_{s} 275-450^{\circ} \mathrm{C}$ from $50 \mathrm{ml}$ of isopropanol-water solution containing $0.2 \mathrm{M}$ (a) $\mathrm{Zn}(\mathrm{ac})_{2}$ or (b) $\mathrm{Zn}(\mathrm{acac})_{2}$ doped with $\mathrm{Al}(\mathrm{acac})_{3}$ [ $[\mathrm{Al}] /[\mathrm{Zn}]$ ratios $0,1,2,3,5,7.5,15$ at.\%

\begin{tabular}{|c|c|c|c|c|c|}
\hline \multirow{2}{*}{$T_{s^{\prime}}\left({ }^{\circ} \mathrm{C}\right)$} & \multirow{2}{*}{$\begin{array}{c}{[A \mid] /[Z n] \text { ratio in }} \\
\text { solution (at.\%) }\end{array}$} & \multicolumn{2}{|c|}{$\operatorname{Zn}(\mathrm{ac})_{2}$} & \multicolumn{2}{|c|}{$\mathrm{Zn}(\mathrm{acac})_{2}$} \\
\hline & & Peak used in eq. (1) & Crystallite size (nm) & Peak used in eq. (1) & Crystallite size (nm) \\
\hline 275 & 7.5 & (101) & 18 & (101) & 28 \\
\hline 350 & 7.5 & (101) & 46 & (101) & 32 \\
\hline 400 & 0 & $(002)$ & 58 & $(002)$ & 40 \\
\hline 400 & 1 & $(002)$ & 30 & $(002)$ & 22 \\
\hline 400 & 2 & $(002)$ & 27 & $(002)$ & 25 \\
\hline 400 & 3 & $(002)$ & 29 & (101) & 19 \\
\hline 400 & 5 & (101) & 30 & (101) & 25 \\
\hline 400 & 7.5 & (101) & 36 & (101) & 31 \\
\hline 400 & 15 & (101) & 26 & (101) & 19 \\
\hline 450 & 7.5 & (101) & 44 & (101) & 9 \\
\hline
\end{tabular}




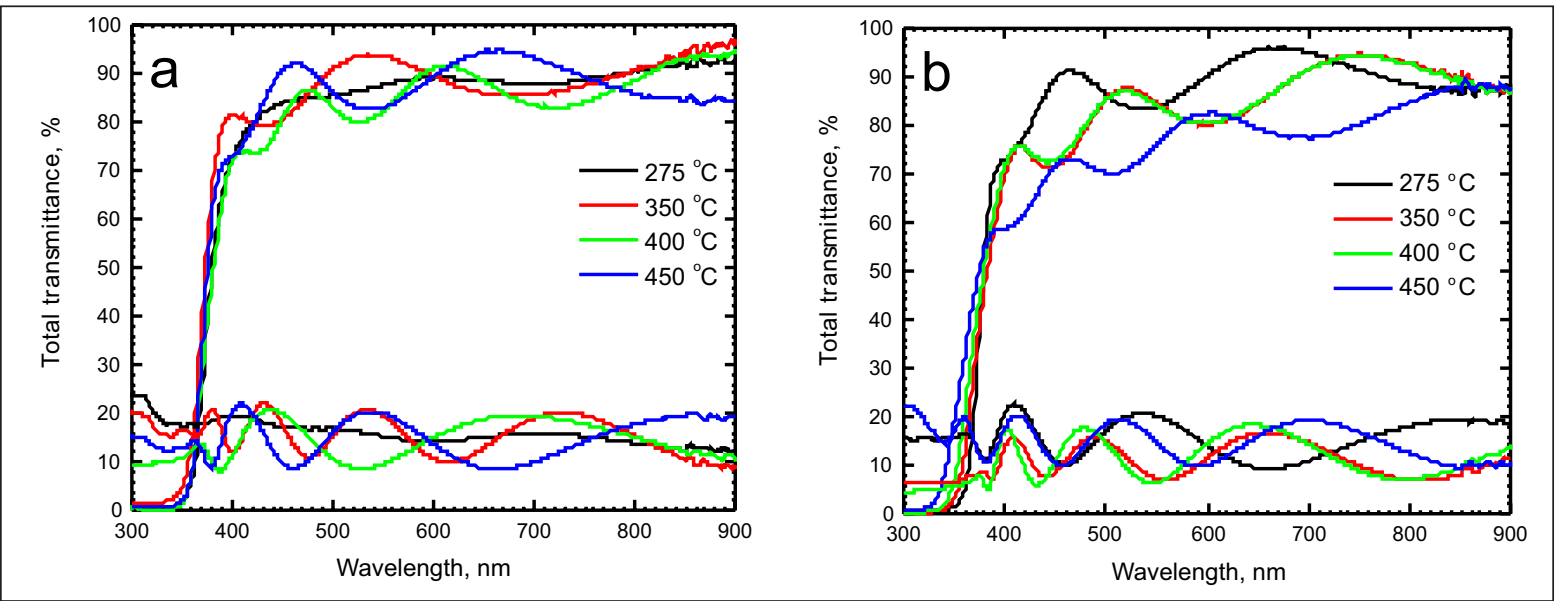

Fig. 5. Optical transmittance spectra of AZO thin films deposited from $50 \mathrm{ml}$ of $0.2 \mathrm{M}$ (a) $\mathrm{Zn}(\mathrm{ac})_{2}$ or (b) $\mathrm{Zn}(\mathrm{acac})_{2}$ doped with Al(acac) at different $T_{s}$ using the $[\mathrm{Al}] /[\mathrm{Zn}]$ ratio 7.5 at.\% in the solution

see Fig. 5a, b. On the other hand, average transmittance decreases from $85 \%$ at $T_{s} 350-400{ }^{\circ} \mathrm{C}$ to $76 \%$ at $450{ }^{\circ} \mathrm{C}\left(400-800 \mathrm{~nm}\right.$ range) for $\mathrm{Zn}(\mathrm{acac})_{2}$ based films (Fig. 5b). AZO films deposited from both precursors at $T_{s} 400{ }^{\circ} \mathrm{C}$ have similar transmittance $\sim 83 \%$ regardless of $\mathrm{Al}$ doping.

The engineering of the band gap is paramount to meeting process specifications in solar cell applications. According to empiric and theoretical results, $\mathrm{ZnO}$ exhibits direct inter-band transitions and for allowed transitions between parabolic bands the following equation is valid [19]:

$$
(\alpha h v)^{2}=\mathrm{A}\left(h v-E_{g}\right),
$$

where $\alpha$ is the absorption coefficient, $h v$ is photon energy, $A$ is a constant, and $E_{g}$ is the band gap.
The interference fringes were eliminated if necessary by using the following equation [28]:

$$
\alpha=\frac{1}{D} \ln \left(\frac{1-R}{T}\right),
$$

where $\alpha$ is the absorption coefficient, $d$ is film thickness, $R$ is total reflectance, and $T$ is total transmittance. $E_{g}$ was determined by plotting $(a h v)^{2}$ against $h v$ and extending a tangent line from the straight part of the resulting straight line portion of the plot as shown in Fig. 6 .

$E_{g}$ in undoped $\mathrm{ZnO}$ films was $3.31 \mathrm{eV}$ when deposited from either zinc precursor. The increase in $E_{g}$ is substantially greater in $\mathrm{Zn}(\mathrm{acac})_{2}$ based films $\left(3.32-3.57 \mathrm{eV}\right.$ vs $3.30-3.43 \mathrm{eV}, T_{\text {s }}$ $400{ }^{\circ} \mathrm{C}, 0-15$ at.\%) possibly due to the formation of inert phases at higher $\mathrm{Al}$ at.\% levels in
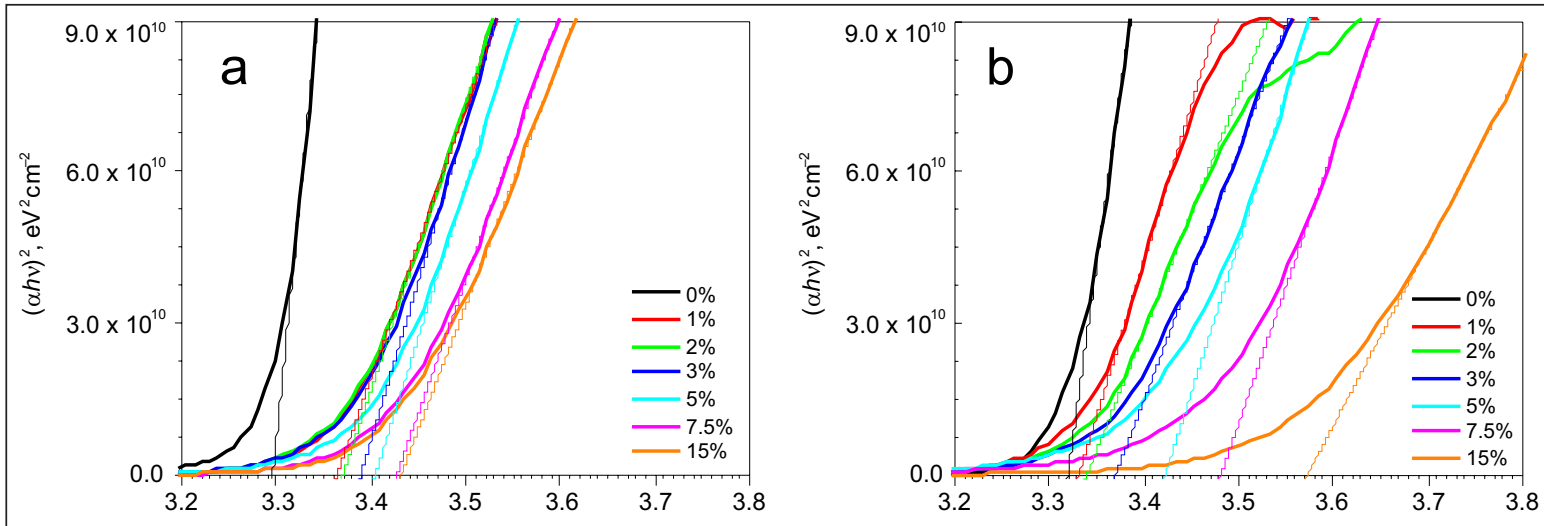

Fig. 6. Plot of $(a h v)^{2}$ versus photon energy (hv) of AZO thin films prepared from $50 \mathrm{ml}$ of $0.2 \mathrm{M}(\mathrm{a}) \mathrm{Zn}(\mathrm{ac})_{2}$ or (b) $\mathrm{Zn}(\mathrm{acac})_{2}$ doped with $\mathrm{Al}(\mathrm{acac})_{3}$ at $T_{s} 400^{\circ} \mathrm{C}$ with the following $[\mathrm{Al}] /[\mathrm{Zn}]$ ratios in the solution: $0,1,2,3,5,7.5,15$ at. $\%$ 
the source solution (Fig. 6a, b). The $E_{g}$ values obtained for 3 at.\% Al-doped $\mathrm{ZnO}$ films deposited at $T_{s} 400{ }^{\circ} \mathrm{C}$ from $\mathrm{Zn}(\mathrm{ac})_{2}(3.39 \mathrm{eV})$ and $\mathrm{Zn}(\mathrm{acac})_{2}(3.37 \mathrm{eV})$ are similar to those obtained by Gómez et al. (3.40-3.47 for 3 at.\%) [9].

The increase in the band gap is mostly explained by the Moss-Burstein effect [5], which is caused by an increase in carrier concentration. $\mathrm{Al}$ is incorporated in the films in increasing quantities until a critical level above which the charge carrier concentration decreases. For the MossBurstein effect to manifest, the carrier concentration must exceed $1 \mathrm{E} 20 \mathrm{~cm}^{-3}$. The blue shift in the band gap in films deposited from $\mathrm{Zn}(\mathrm{acac})_{2}$ in this study is instead probably due to the formation of a wider band gap $\mathrm{AlO}_{\mathrm{x}}$ phase (see Fig. 3b) [29]. This effect is often attributed to the formation of inactive clusters of $\mathrm{AlO}_{x}[5,23]$.

\section{CONCLUSIONS}

The effects of zinc precursor, $[\mathrm{Al}] /[\mathrm{Zn}]$ atomic ratio in the source solution and $T_{s}$ on the physical properties of $\mathrm{Al}$-doped $\mathrm{ZnO}$ thin films were studied. From the structural, optical and electrical measurement results a complex dependence on the aforementioned deposition parameters is established. Zinc acetylacetonate is unsuitable for PSP deposition of highly transparent and conductive AZO films at substrate temperatures higher than $400{ }^{\circ} \mathrm{C}$ due to higher resistivity $(7 \Omega \mathrm{cm}$ at $T_{s} 450{ }^{\circ} \mathrm{C}$ vs $0.7 \Omega \mathrm{cm}$ at $T_{s} 400{ }^{\circ} \mathrm{C}$ ) caused by a smaller crystallite size ( 9 vs $31 \mathrm{~nm}$ ) and reduced optical transmittance in the visible region $(10 \%$ lower average transmittance at $T_{s} 450{ }^{\circ} \mathrm{C}-76 \%$ in 400-800 nm range) due to the formation of a wider band gap, less transparent $\mathrm{Zn}_{6} \mathrm{Al}_{2} \mathrm{O}_{9}$ and $\mathrm{Al}_{2} \mathrm{O}_{3}$ phases. The average crystallite size for 1-5 at.\% $\mathrm{Al}$ in solution $\mathrm{Zn}(\mathrm{acac})_{2}$ based films deposited at $T_{s} 400{ }^{\circ} \mathrm{C}$ is $22 \mathrm{~nm}$ and $29 \mathrm{~nm}$ for $\mathrm{Zn}(\mathrm{ac})_{2}$ based films. Transmittance, mobility and charge carrier concentration are similar for films grown at $T_{s}$ $400{ }^{\circ} \mathrm{C}$. The lowest resistivity is achieved for both types of AZO films at $400{ }^{\circ} \mathrm{C}: 3-7.5$ at.\% [Al]/[Zn] in the source solution for zinc acetate based films $(0.4 \Omega \mathrm{cm})$ and $3-7.5$ at.\% $[\mathrm{Al}] /[\mathrm{Zn}]$ in the source solution for zinc acetylacetonate based films $(0.5 \Omega \mathrm{cm})$. Increasing the $[\mathrm{Al}] /[\mathrm{Zn}]$ ratio to higher than 7.5 at.\% results in higher resistivity films probably due to exceeding critical $\mathrm{Al}$ solubility in the $\mathrm{ZnO}$ lattice and formation of inert secondary $\mathrm{AlO}_{\mathrm{x}}$ phases. Due to stability, higher crystallinity and generally better results in optical and electric properties, zinc acetate is a better zinc precursor for PSP deposition of conductive AZO films at $T_{s}$ $400{ }^{\circ} \mathrm{C}$ using isopropanol-water mixture as solvent.

\section{ACKNOWLEDGEMENTS}

The authors would like to acknowledge the financial support by the Estonian Research Council (IUT19-4) and by the European Regional Development Fund (Centre of Excellence TK141 Advanced materials and high-technology devices for energy recuperation systems).

Received 1 March 2017 Accepted 15 May 2017

\section{References}

1. Badding M., Stefaniak A., Fix N., Cummings K., Leonard S. Cytotoxicity and Characterization of particles collected from an indium-tin oxide production facility. Journal of Toxicology and Environmental Health Part a. 2014. Vol. 77. No. 20. P. 1193-1209.

2. Minami T. Transparent conducting oxide semiconductors for transparent electrodes. Semiconductor Science and Technology. 2005. Vol. 20. No. 4. P. S35-S44.

3. Seeber W. et al. Transparent semiconducting $\mathrm{ZnO}$ :Al thin films prepared by spray pyrolysis. Materials Science in Semiconductor Processing. 1999. Vol. 2. No. 1. P. 45-55.

4. Dghoughi L. et al. The effect of Al-doping on the structural, optical, electrical and cathodoluminescence properties of $\mathrm{ZnO}$ thin films prepared by spray pyrolysis. Physica B: Condensed Matter. 2010. Vol. 405. No. 9. P. 2277-2282.

5. Ravichandran K., Jabena Begum N., Snega S., Sakthivel B. Properties of sprayed aluminum-doped zinc oxide films - A review. Materials and Manufacturing Processes. 2016. Vol. 31. No. 11. P. 1411-1423.

6. Castañeda L. et al. Influence of aluminum concentration and substrate temperature on the physical characteristics of chemically sprayed $\mathrm{ZnO}$ : Al thin solid films deposited from zinc 
pentanedionate and aluminum pentanedionate. Materials Science in Semiconductor Processing. 2010. Vol. 13. No. 2. P. 80-85.

7. Krunks M., Mellikov E. Zinc oxide thin films by the spray pyrolysis method. Thin Solid Films. 1995. Vol. 270. No. 1. P. 33-36.

8. Guild C., Biswas S., Meng Y., Jafari T., Gaffney A., Suib S. Perspectives of spray pyrolysis for facile synthesis of catalysts and thin films: An introduction and summary of recent directions. Catalysis Today. 2014. Vol. 238. P. 87-94.

9. Gómez H., Maldonado A., Castanedo-Pérez R., Torres-Delgado G., De La L. Olvera M. Properties of Al-doped $\mathrm{ZnO}$ thin films deposited by a chemical spray process. Materials Characterization. 2007. Vol. 58. No. 8-9. P. 708-714.

10. Patil P. Versatility of chemical spray pyrolysis technique. Materials Chemistry and Physics. 1999. Vol. 59. No. 3. P. 185-198.

11. Filipovic L. et al. Modeling spray pyrolysis deposition. Proceedings of the World Congress on Engineering \& Computer Science, June 2013.

12. Kriisa M., Krunks M., Kärber E., Kukk M., Mikli V., Mere A. Effect of solution spray rate on the properties of chemically sprayed $\mathrm{ZnO}$ :In thinfFilms. Journal of Nanomaterials. 2013. Vol. 2013. Article ID 423632. P. 1-9.

13. Paraguay D. F., Morales J., Estrada L. W., Andrade E., Miki-Yoshida M. Influence of Al, In, $\mathrm{Cu}, \mathrm{Fe}$ and $\mathrm{Sn}$ dopants in the microstructure of zinc oxide thin films obtained by spray pyrolysis. Thin Solid Films 2000 Vol. 366. No. 1-2. P. 16-27.

14. Sridhar R., Manoharan C., Ramalingam S., Dhanapandian S., Bououdina M. Spectroscopic study and optical and electrical properties of Tidoped $\mathrm{ZnO}$ thin films by spray pyrolysis. Spectrochimica Acta Part A: Molecular and Biomolecular Spectroscopy. 2014. Vol. 120. P. 297-303.

15. Gokulakrishnan V., Parthiban S., Jeganathan K., Ramamurthi K. Investigation on the effect of $\mathrm{Zr}$ doping in $\mathrm{ZnO}$ thin films by spray pyrolysis. Applied Surface Science. 2011. Vol. 257. No. 21. P. 9068-9072.

16. Bouaoud A. et al. Transparent conducting properties of Ni doped zinc oxide thin films prepared by a facile spray pyrolysis technique using perfume atomizer. Materials Chemistry and Physics. 2013. Vol. 137. No. 3. P. 843-847.
17. Gokulakrishnan V., Parthiban S., Jeganathan K., Ramamurthi K. Structural, optical, and electrical properties of $\mathrm{Nb}$-doped $\mathrm{ZnO}$ thin films prepared by spray pyrolysis method. Journal of Electronic Materials. 2011. Vol. 40. No. 12. P. 2382.

18. Swapna R., Santhosh Kumar M. Growth and characterization of molybdenum doped $\mathrm{ZnO}$ thin films by spray pyrolysis. Journal of Physics and Chemistry of Solids. 2013. Vol. 74. No. 3. P. 418-425.

19. Muiva C., Sathiaraj T., Maabong K. Effect of doping concentration on the properties of aluminium doped zinc oxide thin films prepared by spray pyrolysis for transparent electrode applications. Ceramics International. 2011. Vol. 37. No. 2. P. 555-560.

20. Arca E., Fleischer K., Shvets I. Tuning the crystallographic, morphological, optical and electrical properties of $\mathrm{ZnO}$ :Al grown by spray pyrolysis. Thin Solid Films. 2014. Vol. 555. P. 9-12.

21. Jabena Begum N., Ravichandran K. Effect of source material on the transparent conducting properties of sprayed $\mathrm{ZnO}$ :Al thin films for solar cell applications. Journal of Physics and Chemistry of Solids. 2013. Vol. 74. No. 6. P. 841-848.

22. Romero R., Leinen D., Dalchiele E., Ramos-Barrado J., Martín F. The effects of zinc acetate and zinc chloride precursors on the preferred crystalline orientation of $\mathrm{ZnO}$ and $\mathrm{Al}$-doped $\mathrm{ZnO}$ thin films obtained by spray pyrolysis. Thin Solid Films. 2006. Vol. 515. No. 4. P. 1942-1949.

23. Lu J. et al. Carrier concentration dependence of band gap shift in n-type $\mathrm{ZnO}$ :Al films. Journal of Applied Physics. 2007. Vol. 101. No. 8. P. 083705.

24. Joint committee on powder diffraction standards (JCPDS), Powder Diffraction File, Card No. 01075-0576. Swarthmore, PA.

25. Cullity B. D. Elements of X-ray Diffraction, 2nd ed. Boston: Addison-Wesley Longman, Inc. 1978. 575 p. ISBN 978-0-201-01174-6.

26. Manouni A. et al. Effect of aluminium doping on zinc oxide thin films grown by spray pyrolysis. Superlattices and Microstructures. 2006. Vol. 39. No. 1-4. P. 185-192.

27. Prajapati C., Sahay P. Growth, structure and optical characterization of $\mathrm{Al}$-doped $\mathrm{ZnO}$ nanoparticle thin films. Crystal Research and Technology. 2011. Vol. 46. No. 10. P. 1086-1092. 
28. Pankove J., Kiewit D. Optical processes in semiconductors. Journal of The Electrochemical Society. 1972. Vol. 119. No. 5. P. 156C-156C.

29. Li X., Chen T., Liu Y., Leong K. Evolution of dielectric function of $\mathrm{Al}$-doped $\mathrm{ZnO}$ thin films with thermal annealing: effect of band gap expansion and free-electron absorption. Optics Express. 2014. Vol. 22. No. 19. P. 23086-23093.

Jako Siim Eensalu, Malle Krunks, Inga Gromyko, Atanas Katerski, Arvo Mere

ALIUMINIU LEGIRUOTŲ CINKO OKSIDO
PLONŲJŲ DANGŲ FORMAVIMAS
PNEUMATINIO PURŠKIMO PIROLIZĖS
METODU NAUDOJANT CINKO ACETATĄ
IR CINKO ACETILACETONATĄ BEI
PALYGINAMASIS GAUTŲ JUNGINIŲ
FIZIKINIŲ SAVYBIŲ VERTINIMAS

Santrauka

Darbe pristatoma didelio optinio pralaidumo, laidžių aliuminiu legiruoto cinko oksido (AZO) dangu palyginamoji analizè formuojant jas pneumatinio purškimo pirolizès metodu. Dangos buvo formuojamos ant natrio-kalcio silikatinio stiklo purškimo metu naudojant cinko acetato ir cinko acetilacetonato pagrindo tirpalus. Struktūrinès, optinès ir elektrinès dangų savybès buvo analizuojamos priklausomai nuo aliuminio kiekio pirminiame tirpale ir padèklo temperatūros dan- gų formavimo metu $\left(T_{s}\right)$. Tirpalas, naudojamas formuojant dangas, sudarytas iš $0,2 \mathrm{M}$ cinko acetato arba $0,2 \mathrm{M}$ cinko acetilacetonato ir aliuminio acetilacetonato (Al/Zn santykis: 0-15 atom. \%). Padèklo temperatūra kito nuo 275 iki $450{ }^{\circ} \mathrm{C}$. Optinio pralaidumo ir atspindžio spektrai buvo matuojami UV-VIS-NIR spektroskopu. Varža, krūvio judrumas ir pernašos tankis įvertinti naudojant keturių zondų metodą esant standartinėms aplinkos sąlygoms. Rentgeno spindulių difrakcijos analizè parodė, kad AZO dangos yra labiausiai orientuotos c-ašimi, kai Al/Zn koncentracijų santykis pirminiame tirpale siekia 2-3 atom. \%. Kristalitu dydis, kai padèklo temperatūra $T_{s}$ dangų formavimo metu $400{ }^{\circ} \mathrm{C}$, yra 25-30 nm. Visos suformuotos AZO dangos pasižymi dideliu vidutiniu optiniu pralaidumu (76-94 \%) regimąjame 400-800 nm bangų spektre. Eg vertè kito nuo 3,32 eV nelegiruotame $\mathrm{ZnO}$ junginyje iki 3,58 eV itin legiruotose AZO dangose naudojant cinko acetilacetonato pagrindo tirpalą. Šis pokytis ìvyko dèl antrinių $\mathrm{AlO}_{\mathrm{x}}$ fazių formavimosi. Mažiausia varžos vertè $(0,40 \Omega \times \mathrm{cm})$ fiksuota, kai temperatūra dangos formavimo metu buvo $400{ }^{\circ} \mathrm{C}$ naudojant cinko acetatą (Al/Zn santykis tirpale 3-7,5 atom. \%) ir $0,47 \Omega \times \mathrm{cm}$ naudojant cinko acetilacetonatą (koncentracija 3-7,5 atom. \%, kai temperatūta dangos formavimo metu $\left.-400{ }^{\circ} \mathrm{C}\right)$.

Raktažodžiai: aliuminiu legiruotas cinko oksidas (AZO), $\mathrm{Al}$ legiruotas $\mathrm{ZnO}$, pneumatinis purškimo pirolizès metodas, plonosios dangos 